\title{
Changes in HPV infection in patients with anogenital warts and their partners
}

\author{
R J Hillman, B K Ryait, M Botcherby, D Taylor-Robinson
}

\begin{abstract}
Objectives-To investigate the relationship between clinical findings and the detection of human papillomavirus (HPV) DNA in a range of anatomical sites in patients with and without anogenital warts.

Subjects-Men and women with a clinical diagnosis of anogenital warts, or a current partner with anogenital warts.

Setting-A department of genitourinary medicine in central London.

Methods-The anogenital areas of the patients were thoroughly examined using a colposcope before and after application of acetic acid. Different types of specimens were taken from a variety of anatomical sites. Superficial skin sampling was performed by the application of slides covered with "Superglue" (SG) to clinically normal and abnormal areas of anogenital skin. The presence of human cells in the SG samples was confirmed by detection of the $\beta$-globin gene using the polymerase chain reaction (PCR). HPV DNA was extracted from the specimens and amplified by using consensus primers with the PCR. HPV types $6,11,16,18,31$ and 33 were identified by Southern blotting followed by hybridisation.
\end{abstract}

Results-In women, HPV DNA was detected in $83 \%$ of wart biopsies, $29 \%$ of cervical biopsies, $36 \%$ of cervical scrapes, $25 \%$ of urethral loop specimens, $37 \%$ of vaginal washes and $33 \%$ of rectal swab specimens. In men, HPV DNA was detected in $67 \%$ of wart biopsies, $37 \%$ of urethral loop specimens and $12 \%$ of rectal swab specimens. Of the SG samples containing the $\beta$-globin gene, $49 \%$ from women and $50 \%$ from men contained HPV DNA. HPV DNA was not detected in buccal scrapes and serum samples from women or men. Of all specimens with detectable HPV DNA, there was evidence of a single HPV type in $41 \%$, multiple types in $\mathbf{4 8 \%}$ and undetermined types in $11 \%$. Samples taken from different sites of a patient tended to have HPV types in common. Sexual partners, however, did not consistently have HPV types in common.

Conclusions-HPV DNA was distributed widely in the anogenital area, in warts, acetowhite areas and clinically normal skin. The SG technique was well tolerated by patients and produced results consistent with other findings. Sampling from a single site of the genitalia on one occasion may significantly underestimate the infection rate with HPV. Multifocal infection of the anogenital area with HPV should be taken into consideration when interpreting epidemiological studies and management strategies.

(Genitourin Med 1993;69:450-456)

\section{Introduction}

Although there is considerable evidence that condylomata acuminata are usually sexually transmitted, ${ }^{12}$ the epidemiology of clinically inapparent infection with genitotropic human papillomavirus (HPV) types is less well understood. ${ }^{3}$ Studies of the uterine cervix have shown that HPV infection is common, may not be associated with cytological ${ }^{4}$ or histological ${ }^{5}$ abnormalities and has epidemiological characteristics which suggest that sexual transmission may not be the only mode of acquisition. ${ }^{6}$ Furthermore, the relationship between the detection of HPV and the development of histological and/or clinical changes is imperfectly understood, and the relationship may vary with time. ${ }^{7}$

In an attempt to characterise the multifocal nature of HPV infection and its possible change with time, we took a variety of samples over several months from patients with and without genital warts. The patients comprised those. with anogenital warts and their partners who may or may not have had warts. Following extraction of DNA from the specimens, the polymerase chain reaction (PCR) was used, as this is currently the most sensitive technique for the detection of HPV. ${ }^{8}$ Southern blotting ${ }^{9}$ was then performed, as it allows the highly specific confirmation of DNA sequences produced by the PCR and enables the type of HPV to be determined.

\section{Patients and methods}

\section{COLLECTION OF SPECIMENS}

Patients were invited to take part in the study if either they or their sexual partner had clinically apparent anogenital warts. A standard history was taken and all patients were screened for the commonly occurring sexually transmitted diseases, and treated when appropriate. The genital and perigenital areas were then examined with the naked eye and any abnormalities documented diagrammatically.

\author{
Address correspondence to: \\ Dr R J Hillman, The \\ Ambrose King Centre, The \\ Royal London Hospital, \\ E1 1BB \\ 1NY, UK \\ Botcherb
}


After application of 3-5\% acetic acid to these areas, microscopic examination using a Zeiss colposcope was undertaken.

Informed consent was obtained from the patients and then samples were taken in the conventional manner as follows: $10 \%$ l plastio loops (Nunc, Gibco, Paisley, Scotland) for urethral specimens, Ayre's spatulas for cervical scrapes and cytological brushes ("Cytobrush", Rocket, London, UK) for endocervical specimens. Anal samples were obtained by inserting a Cytobrush $1 \mathrm{~cm}$ into the anal canal and rotating it through $360^{\circ}$. Tongue depressors were drawn along the buccal surface of both sides of the mouth to obtain buccal scrapes. The tips of the sampling instruments used in the aforementioned procedures were broken off into individual disposable bottles containing $10 \mathrm{ml}$ of phosphate-buffered saline (PBS). A vaginal sample was obtained by washing the vaginal walls and cervix with $10 \mathrm{ml}$ of normal saline using a sterile syringe, aspirating the fluid and repeating the procedure. Blood was obtained using the "Vacutainer" (Becton Dickinson, Cowley, UK) system. Superficial layers of the skin were sampled by using "Superglue" (SG) cyanoacrylate glue (Bison ${ }^{\mathrm{TM}}$, Perfecta Chemie B.V., Goes, Holland). One drop of SG was placed on a clean slide which was immediately applied to the skin. After one minute, the slide was gently removed and placed in an individual slide box. This procedure was well tolerated by patients. If possible, SG samples were taken from areas of skin containing warts, or areas of skin including acetowhite changes. Biopsies of the external genital area were taken by the skin snip technique ${ }^{10}$ following local anaesthesia. Biopsy specimens were taken from warts and acetowhite areas in women but only from warts in men. Cervical biopsy samples were obtained by cervical biopsy forceps without anaesthesia. Biopsy specimens were placed in PBS for DNA analysis and in formal saline for histopathological assessment.

Strict precautions against contamination of the specimens by HPVs were taken. All sampling instruments, except those used for taking biopsy specimens, were sterile and disposable. Biopsy specimens were taken with re-usable equipment which was hand-washed, placed in an ultrasonic cleaner (Olympus Keymed KS-2; Keymed, Southend on Sea, UK) for $15 \mathrm{~min}$ and autoclaved at $134^{\circ} \mathrm{C}$ for $20 \mathrm{~min}$ (Little Sister 2, Eschmann Bros \& Walsh Ltd, Lancing, UK) before re-use. All specimens were collected using a "no touch" technique and placed in sterile, disposable bottles prior to analysis.

To facilitate interpretation of results, specimens were divided into three groups. "Biopsy" specimens consisted of specimens from clinically abnormal and acetowhite areas. SG specimens consisted of samples obtained using the SG technique. The term "non-biopsy" is used to describe all other types of specimens.

Clinically apparent warts were treated in the usual manner for the clinic, namely, the application of liquid nitrogen and 15\% podophyllin, both twice weekly until clinical disappearance. Warts that recurred were treated in a similar manner and any subsequent recurrence managed by excision under loeal anaesthesia.

Patients were counselled and kept fully informed of any abnormality. Male patients and male partners of patients were advised to use condoms for the whole study period.

\section{PROCESSING OF SPECIMENS}

In order to avoid cross-contamination of DNA products, preparation of reagents, processing of patient material, and the PCR and Southern blotting took place in separate rooms. Positive displacement pipettes or single-use Pasteur pipettes were used for distributing reagents for the PCR and for adding the DNA samples to the reaction mixtures. Positive and negative controls were included in each experiment, including the SG samples.

\section{DNA EXTRACTION}

Wart and biopsy specimens were placed in $320 \mu \mathrm{l}$ of lysis buffer containing $160 \mu \mathrm{l}$ of $2 \times$ Summers' buffer, pH 8.0 (40 mM TRIS$\mathrm{HCl}, 0.3 \mathrm{M} \mathrm{NaCl}$ and $20 \mathrm{mM}$ EDTA-tetra sodium salt), $100 \mu \mathrm{l}$ of double distilled $\mathrm{H}_{2} \mathrm{O}$ $\left(\mathrm{ddH}_{2} \mathrm{O}\right), 32 \mu \mathrm{l}$ of pronase $\mathrm{E}(10 \mathrm{mg} / \mathrm{ml}), 28$ $\mu \mathrm{l}$ of $2.5 \%$ sodium dodecyl sulphate (SDS) and $4 \mu \mathrm{l}$ of t-RNA $(0 \cdot 8 \mathrm{mg} / \mathrm{ml})$. Sterile glass beads were added to the biopsy specimens to facilitate the disruption of cells during vortexing.

SG slides were abraded with a sterile disposable scalpel blade and the resulting material immersed in $320 \mu \mathrm{l}$ of lysis buffer. SDS in the lysis buffer dissolved the cyanoacrylate in the specimen, releasing the sample material into the buffer.

Wart, biopsy and SG specimens were incubated in the buffer at $37^{\circ} \mathrm{C}$ overnight to help cells and disrupt proteins. DNA was isolated from the specimens using phenol extraction, followed by a chloroform-isoamyl alcohol (24:1) extraction and ethanol precipitation for $1 \mathrm{hr}$ at $-70^{\circ} \mathrm{C}$. The DNA pellet was collected after centrifugation for $10 \mathrm{~min}$ at $10,000 \mathrm{~g}$, washed briefly with $70 \%$ ethanol and dried under vacuum for $30 \mathrm{~min}$. The resulting pellet was then resuspended in $40 \mu \mathrm{l}$ $\mathrm{ddH}_{2} \mathrm{O}$ and stored at $-70^{\circ} \mathrm{C}$ until further analysis.

Urethral loops, cervical and buccal scrapes and Cytobrush specimens were agitated in 10 $\mathrm{ml}$ of PBS, of which $1.5 \mathrm{ml}$ was subsequently used for analysis. Vaginal washes were tested directly. These samples were subsequently denatured by heating to $95^{\circ} \mathrm{C}$ for $10 \mathrm{~min}$ and then centrifuged at $10,000 \mathrm{~g}$ for $2 \mathrm{~min}$ to remove cellular debris and other extraneous material. The supernatant fluid was then used for the PCR.

Blood samples were centrifuged at 2000 $\mathrm{rpm}$ for $5 \mathrm{~min}$ and the serum decanted. This was used directly for the PCR.

DETECTION OF $\beta$-GLOBIN GENE

In order to determine whether human DNA 


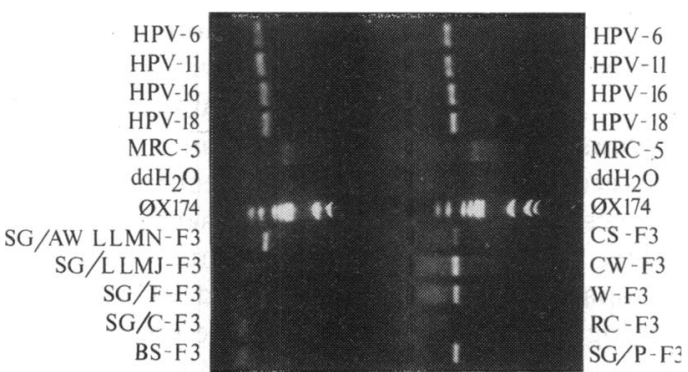

Figure 1 Ethidium bromide staining of agarose gel comprising positive controls (HPV types 6,11,16 and 18), negative controls (MRC-5 fibroblasts and dd $\mathrm{H}_{2} \mathrm{O}$ ), molecular weight marker $\phi X 174$ ( $\phi X 174$ DNA cut with Hae III enzyme) and specimens of DNA from patient F3. Abbreviations for the specimen descriptions are as follows: $S G=$ Superglue specimen; $A W=$ specimen taken from acetowhite area; LLMN = left labium minus; $L L M F=$ left labium majus; $F=$ fourchette; $C=$ clitoris; $B S=$ buccal smear; $C S=$ cervical scrape; $C W=$ cervical wart; $W=$ external wart; $R C=$ rectal cytobrush; $P=$ perianal area. Positive results seen for HPV controls, $S G$ specimens from the fourchette and perianal area, as well as an acetowhite area on the left labium minus. Cervical scrape, cervical wart and vulval wart specimens also contain HPV DNA.

was detectable in the SG samples, part of the human $\beta$-globin gene was amplified. Amplification was carried out using $100 \mu \mathrm{l}$ of reaction mixture containing $50 \mathrm{mM} \mathrm{KCl,} 10$ $\mathrm{mM}$ TRIS- $\mathrm{HCl} \mathrm{pH} 8 \cdot 3,0.01 \% \mathrm{w} / \mathrm{v}$ gelatin, $200 \mu \mathrm{M}$ each of dATP, dCTP, dGTP, and dTTP, $3.5 \mathrm{mM} \mathrm{MgCl}, 2.5$ units of Taq polymerase (GIBCO-BRL, Paisley, Scotland) and $0.2 \mu \mathrm{M}$ each of two $\beta$-globin primers ${ }^{11}$ (kindly provided by the Medical Research Council AIDS Directed Programme): $\beta$-globin (1433) ADP894-1/LA1-N: 5'ACA CAA CTG TGT TCA CTA GG $3^{\prime}$ and $\beta$-globin (123104) ADP 894.2/LA2-C: 5'CAA CTT CAT CCA CGT TCA CC 3'. The specimens were then subjected to 40 cycles of amplification. Each cycle included denaturation at $94^{\circ} \mathrm{C}$ for $30 \mathrm{~s}$, primer annealing at $55^{\circ} \mathrm{C}$ for $30 \mathrm{~s}$ and chain elongation at $72^{\circ} \mathrm{C}$ for $60 \mathrm{~s}$. Positive controls were a fibroblast line derived from embryonic lung tissue (MRC-5) and an epithelial cell line derived from cervical carcinoma tissue ( $\mathrm{HeLa}-229) . \mathrm{ddH}_{2} \mathrm{O}$ was used as a negative control.

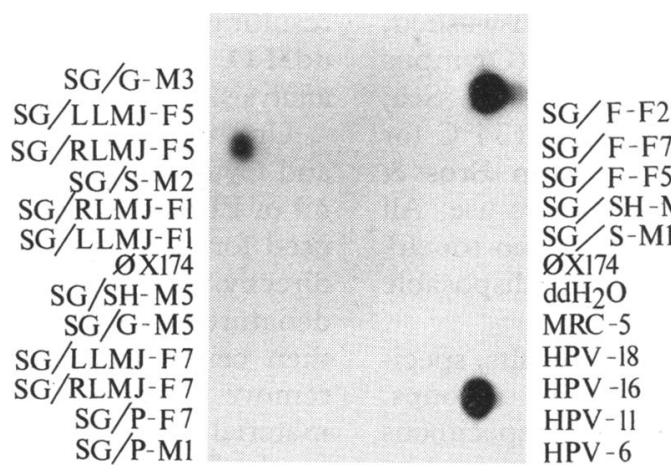

Figure 2 Hybridisation of PCR products with HPV type 11 -specific probe on nylon membrane following Southern blot. Abbreviations as for fig 1 and as follows: $G=$ glans; $R L M F=$ right labium majus; $S=$ scrotum; $S H=$ shaft. Positive results seen for HPV type 11 control, SG specimen from the scrotum of patient $M 2$ and $S G$ specimen from the fourchette of patient F2.
DETECTION OF HPV DNA

In the case of SG samples, only those containing detectable human $\beta$-globin DNA were tested for HPV DNA, whereas all specimens obtained by other methods were tested. The DNA extracted was amplified by 40 cycles of the PCR using general primers GP5 and GP6 which amplifies DNA from HPV types 6,11 , $16,18,31$ and $33 .{ }^{12}$ Amplification was carried out using $100 \mu \mathrm{l}$ of reaction mixture containing $50 \mathrm{mM} \mathrm{KCl}, 10 \mathrm{mM}$ Tris $\mathrm{HCl} \mathrm{pH}$ $8.3,3 \mathrm{mM} \mathrm{MgCl}, 0.01 \% \mathrm{w} / \mathrm{v}$ gelatin, 200 $\mu$ moles each of dGTP, dATP, dTTP and dCTP, $10 \mu$ moles each of GP5 and GP6 ${ }^{12}$ primers and 2.5 units of $T a q$ polymerase (GIBCO-BRL, Paisley, Scotland). This mixture was overlaid with $100 \mu \mathrm{l}$ of mineral oil to prevent water loss and subjected to 40 cycles of amplification using a PCR processor (Hybaid, Teddington, UK). Each cycle included denaturation at $94^{\circ} \mathrm{C}$ for $20 \mathrm{~s}$, annealing at $40^{\circ} \mathrm{C}$ for $60 \mathrm{~s}$ and chain elongation at $72^{\circ} \mathrm{C}$ for $20 \mathrm{~s}$. Samples containing 100 $\mathrm{pg}$ of the full length genome of HPV types 6, 11,16 and 18 were used as positive controls. Negative controls were a fibroblast line (MRC-5) and $\mathrm{ddH}_{2} \mathrm{O}$ (fig 1). Detection of the products of the PCR was by agarose gel electrophoresis, confirmed by Southern blotting $^{13}$ and hybridisation with radiolabelled oligonucleotide probes. $^{14}$ Positive controls were full length genomic probes for HPV types $6,11,16$ and 18 . Negative controls were MRC-5, ddH $\mathrm{H}_{2} \mathrm{O}$ and "Superglue". Examples of this can be seen in figs 2 and 3.

\section{Results}

CHARACTERISTICS OF PATIENTS

Nine women and nine men took part in the study. All patients were heterosexual. The mean age of the women was $24 \cdot 0$ years (range $16 \cdot 1$ to $36 \cdot 2$ ) and that of the men 28.4 years (range $22 \cdot 9$ to $36 \cdot 3$ ). Clinical details of the patients are shown in tables 1 and 2 ; there were four pairs of partners (F1-M3, F2-M8,

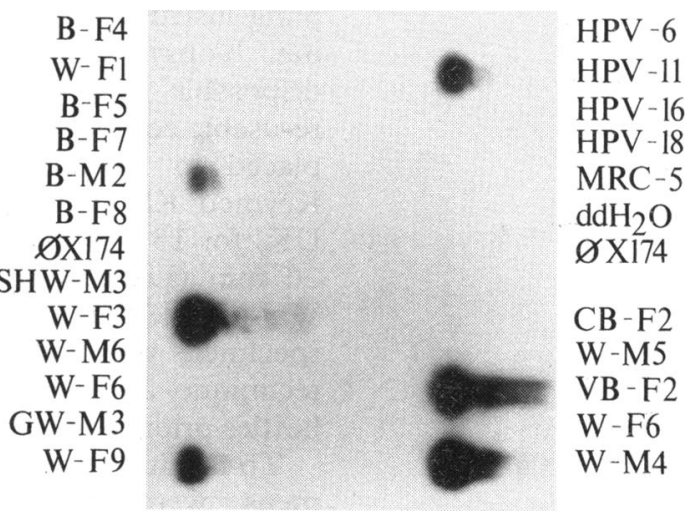

Figure 3 Hybridisation of PCR products with HPV type 11 -specific probe on nylon membrane following Southern blot. Abbreviations as for fig 1 and as follows: $B=$ biopsy, $S H W=$ shaft wart; $G W=$ glans wart; $C B=$ cervical biopsy; VB = vulval biopsy. In women, biopsies were either from acetowhite areas or from clinically apparent warts. In men biopsies were always taken from clinically apparent warts. Positive results seen for HPV type 11 control, biopsies from patients $M 2$ and $F 2$, and warts from F9 and M4. 
Table 1 Clinical, histological and cytological details of female patients

\begin{tabular}{|c|c|c|c|c|}
\hline$P_{t}$ & $\begin{array}{l}\text { Sites of } \\
\text { visible } \\
\text { warts }\end{array}$ & $\begin{array}{l}\text { Sites of } \\
\text { acetowhite } \\
\text { change }\end{array}$ & $\begin{array}{l}\text { Status } \\
\text { of } \\
\text { partner }\end{array}$ & $\begin{array}{l}\text { Cervical } \\
\text { biopsy: } \\
\text { histological changes }\end{array}$ \\
\hline $\begin{array}{l}\text { F1 } \\
\text { F2 } \\
\text { F3 } \\
\text { F4 } \\
\text { F5 } \\
\text { F6 } \\
\text { F7 } \\
\text { F8 none } \\
\text { F9 }\end{array}$ & $\begin{array}{l}\text { none } \\
\text { fourchette } \\
\text { fourchette, cervix } \\
\text { fourchette, cervix } \\
\text { fourchette, cervix } \\
\text { none } \\
\text { none } \\
\text { labia } \\
\text { fourchette, labia }\end{array}$ & $\begin{array}{l}\text { cervix } \\
\text { cervix } \\
\text { labia } \\
\text { cervix, labia } \\
\text { labia, cervix } \\
\text { cervix } \\
\text { labia } \\
\text { warts } \\
\text { labia }\end{array}$ & $\begin{array}{l}\text { warts }(M 3) \oint \\
\text { warts (M8)§ } \\
\text { warts (M2)§ } \\
\text { warts } \\
\text { no warts } \\
\text { no warts } \\
\text { no warts (M9) } \\
\text { ns } \\
\text { no warts }\end{array}$ & $\begin{array}{l}\text { NAD } \\
\text { ns } \\
\text { CIN 1, WVI } \\
\text { NAD } \\
\text { koil } \\
\text { NCI } \\
\text { ns } \\
\text { ns }\end{array}$ \\
\hline
\end{tabular}

Abbreviations used in tables:

$\mathrm{Pt}=$ patient code.

$\oint=$ partner in the study as indicated.

ns $=$ no specimen obtained

$\mathrm{NAD}=$ no histological or cytological abnormality detected.

wart $=$ histological changes of condylomatous wart virus infection.

CIN 1 = cervical intraepithelial neoplasia grade 1 .

$\mathrm{NCI}=$ histological changes of non-condylomatous HPV infection.

koil $=$ koilocytic atypia .

Time = duration in months since first sample taken.

neg $=$ HPV types $6,11,16,18,31$ and 33 not detected.

$\star=$ biopsy from clinically apparent wart.

$+=$ specimen contained HPV of types other than those tested for; $\beta=\beta$-globin gene not

detected.

Table 2 Clinical and histological details of male patients

\begin{tabular}{llll}
\hline Pt & $\begin{array}{l}\text { Sites of } \\
\text { visible } \\
\text { warts }\end{array}$ & $\begin{array}{l}\text { Sites of } \\
\text { acetowhite } \\
\text { change }\end{array}$ & $\begin{array}{l}\text { Status } \\
\text { of } \\
\text { partner }\end{array}$ \\
\hline M1 & shaft & none & cervical dysplasia \\
M2 & shaft, inguinal & $\begin{array}{l}\text { glans } \\
\text { glans }\end{array}$ & warts (F3)@ \\
M3 & shaft & norts (F1) \\
M4 & meatus, glans & glans & no warts \\
M5 & shaft, inguinal & none & no warts \\
M6 & corona & corona & warts \\
M7 & shaft, glans & glans & warts \\
M8 & shaft & glans & warts (F2)@ \\
M9 & glans & glans & nowarts (F7) \\
\hline
\end{tabular}

F3-M2 and F7-M9), the partners of the other patients not being available for study. Patient F6 was referred by her general practitioner because of a suspicion of genital warts seen at the time of taking a cervical scrape. There was no evidence of anogenital warts at the time of assessment in the clinic, but a papillary lesion noted in the vagina was biopsied and found to be a skin tag. Four women (F1, F2, F5 and F7) and two men (M1 and M2) did not have skin biopsies. Apart from these, all other biopsies taken from clinically apparent warts were confirmed histologically as such. Biopsy of acetowhite changes on the labia of patient F8 showed changes of HPV infection.
OCCURRENCE OF HPV DNA IN BIOPSY, NON-BIOPSY AND SG SPECIMENS

Biopsy specimens

HPV DNA was detected in five $(83 \%)$ of six biopsy specimens, with histological evidence of HPV infection, from women (tables 1 and 3 ) and in six (67\%) of nine from men (table 4). None of four biopsies of acetowhite areas in the women contained HPV DNA, nor did the biopsy of the skin tag (table 3). Two $(29 \%)$ of seven cervical biopsies contained HPV DNA, of which one was histologically abnormal (tables 1 and 3).

\section{Non-biopsy specimens}

In women (table 3), HPV DNA was detected in the following specimens: four (36\%) of 11 cervical scrapes, two (25\%) of eight from the urethra, three $(37 \%)$ of eight from the vagina, two $(33 \%)$ of six from the rectum and none of five buccal scrapes (patients F1, F2, F3, F4 and F7). Patients F4 and F5 had borderline cervical cytological changes. Both these cervical samples contained HPV DNA (table 3).

In men (table 4), HPV DNA was detected in the following specimens: three $(37 \%)$ of 8 from the urethra, $1(12 \%)$ of 8 from the rectum and none of five buccal scrapes (patients M1, M2, M3, M6 and M9).

Serum samples from all nine men and six of the nine women did not contain HPV DNA.

\section{SG specimens}

Forty SG samples were taken from women (table 5) and 41 from men (table 4). Thirtyseven $(92 \%)$ of those from women and 18 $(44 \%)$ of those from men contained the $\beta$ globin gene. Of the samples containing the $\beta$ globin gene, 18 (49\%) from women and nine (50\%) from men contained HPV DNA, detection rates which compare favourably with those of non-biopsy procedures.

Of SG samples from acetowhite areas, HPV DNA was detected in those from the labia of four of five women (tables 1 and 5) and in those from the glans of two of four men (tables 2 and 4).

Of the six men with shaft warts (table 2), HPV DNA was detected in the shaft SG specimens of four of the five men whose shaft

Table 3 HPV DNA in biopsy and non-biopsy specimens from women in relation to types of specimens and times at which taken

\begin{tabular}{|c|c|c|c|c|c|c|c|}
\hline \multirow[b]{2}{*}{ Pt } & \multirow[b]{2}{*}{ Time } & \multicolumn{6}{|c|}{ HPV DNA in sites and types of specimen indicated } \\
\hline & & $\begin{array}{l}\text { Vulval } \\
\text { biopsy }\end{array}$ & $\begin{array}{l}\text { Cervical } \\
\text { biopsy }\end{array}$ & $\begin{array}{l}\text { Cervical } \\
\text { scrape }\end{array}$ & $\begin{array}{l}\text { Urethral } \\
\text { loop }\end{array}$ & $\begin{array}{l}\text { Vaginal } \\
\text { wash }\end{array}$ & $\begin{array}{l}\text { Rectal } \\
\text { swab }\end{array}$ \\
\hline F1 & $\begin{array}{l}0 \\
4 \\
12\end{array}$ & $\begin{array}{l}\text { neg } \\
\text { neg } \\
\text { ns }\end{array}$ & $\begin{array}{l}6 \\
\text { neg } \\
\text { ns }\end{array}$ & ns & $\begin{array}{l}\text { neg } \\
\text { neg }\end{array}$ & neg & $\begin{array}{l}\text { neg } \\
\text { ns }\end{array}$ \\
\hline F2 & 0 & $\begin{array}{l}\text { ns } \\
6,11,31^{*}\end{array}$ & $\begin{array}{l}\text { ns } \\
\text { ns }\end{array}$ & $\begin{array}{l}\text { neg } \\
\text { ns }\end{array}$ & $\begin{array}{l}\text { ns } \\
\text { ns }\end{array}$ & $\begin{array}{l}\text { neg } \\
\text { ns }\end{array}$ & $\begin{array}{l}\text { ns } \\
\text { ns }\end{array}$ \\
\hline F3 & $\begin{array}{l}4 \\
0\end{array}$ & $\begin{array}{l}\text { ns } \\
6,11^{*}\end{array}$ & $\begin{array}{l}\text { neg } \\
\text { ns }\end{array}$ & $\begin{array}{l}\text { neg } \\
6,11,33\end{array}$ & & 18,31 & 6,11 \\
\hline 10 & 2 & $6,11^{\star}$ & $\begin{array}{l}\text { ns } \\
6,11^{\star}\end{array}$ & $\begin{array}{l}6,11,33 \\
\text { neg }\end{array}$ & $\begin{array}{l}6,11,33 \\
\text { ns }\end{array}$ & $\begin{array}{l}\text { ns } \\
\text { ns }\end{array}$ & $\begin{array}{l}\text { ns } \\
\text { ns }\end{array}$ \\
\hline F4 & 0 & $6^{\star}$ & neg* & 6 & 6 & + & 6 \\
\hline F5 & 0 & neg $^{\star}$ & neg ${ }^{\star}$ & 6 & neg & ns & ns \\
\hline F6 & 0 & neg & ns & neg & neg & neg & neg \\
\hline $\begin{array}{l}\text { F7 } \\
\text { F8 }\end{array}$ & 0 & neg & ns & + & neg & 16 & ns \\
\hline F9 & $\begin{array}{l}0 \\
0\end{array}$ & $\begin{array}{l}\text { neg } \\
6,11^{\star}\end{array}$ & neg & neg & ns & ns & neg \\
\hline & 0 & 0,11 & neg & neg & neg & neg & neg \\
\hline
\end{tabular}


Table 4 HPV DNA in biopsy, non-biopsy and SG specimens from men in relation to types of specimens and times at which taken

\begin{tabular}{|c|c|c|c|c|c|c|c|c|}
\hline \multirow[b]{3}{*}{$P t$} & \multirow[b]{3}{*}{ Time } & \multicolumn{7}{|c|}{ HPV DNA in sites and types of specimen indicated } \\
\hline & & \multirow[b]{2}{*}{ Biopsy } & \multirow[b]{2}{*}{ Urethral loop } & \multirow[b]{2}{*}{ Rectal swab } & \multicolumn{4}{|c|}{ SG specimens from } \\
\hline & & & & & Glans & Shaft & Scrotum & Anus \\
\hline M1 & $\mathbf{0}$ & ns & ns & ns & $\beta$ & $\beta$ & ns & neg \\
\hline & 7 & ns & ns & ns & $\beta$ & 18 & neg & $\beta^{\circ}$ \\
\hline \multirow[t]{2}{*}{ M2 } & 0 & ns & ns & neg & $\boldsymbol{\beta}^{2}$ & $\beta^{2}$ & $6,11,18$ & $\beta$ \\
\hline & 4 & 6,11 & 6 & neg & neg & ns & ns & ns \\
\hline \multirow[t]{2}{*}{ M3 } & 0 & neg & ns & ns & neg & 18 & ns & ns \\
\hline & 4 & ns & neg & neg & neg & neg & $\beta^{-}$ & ns \\
\hline \multirow[t]{2}{*}{ M4 } & 0 & 6,11 & $6,11,16$ & 6,11 & 6,11 & + & ns & $\beta$ \\
\hline & 3 & ns & & ns & neg & $\beta^{-}$ & $\beta^{2}$ & $\beta$ \\
\hline \multirow{6}{*}{$\begin{array}{l}\text { M5 } \\
\text { M6 } \\
\text { M7 }\end{array}$} & 0 & 6 & neg & neg & 18 & 6 & ns & ns \\
\hline & 0 & 6 & neg & neg & 6,31 & $\beta$ & ns & ns \\
\hline & 0 & ns & ns & ns & $\beta^{2}$ & $\beta^{2}$ & ns & ns \\
\hline & 1 & 6,33 & 6 & neg & ns & ns & ns & ns \\
\hline & 2 & 6,11 & ns & ns & ns & ns & ns & ns \\
\hline & 3 & ns & ns & ns & $\beta$ & neg & $\beta$ & $\beta^{2}$ \\
\hline M8 & 0 & neg & neg & neg & $\beta$ & 18 & ns & neg \\
\hline M9 & 0 & 6 & neg & ns & $\beta$ & $\beta$ & $\beta$ & $\boldsymbol{\beta}^{0}$ \\
\hline
\end{tabular}

SG wart specimens contained the $\beta$-globin gene (table 4). Similarly, HPV DNA was detected in the fourchette SG samples from all 3 women with fourchette warts who had this sample taken (tables 1 and 5).

HPV DNA AND TYPES IN RELATION TO SAMPLE SITE AND TIME OF SAMPLING

Site and time of sampling

Of the 12 possible sites in women (tables 3 and 5) from which samples could have been taken on each occasion, $0-8$ (mean $2 \cdot 8$ ) contained HPV DNA. Of the eight possible sites in men (table 4) from which samples could have been taken on each occasion, 1-5 (mean 1.25) contained HPV DNA.

Of the 8 patients from whom samples were taken on more than one occasion (tables 3-5), five had HPV DNA detected in fewer sites and two in more sites than when first seen. In one patient, the number of sites in which HPV DNA was detected initially increased, but then decreased.

\section{Types of HPV detected}

Of the 56 samples in which HPV DNA was detected, 23 ( $41 \%)$ had evidence of infection with a single type, 27 (48\%) with multiple types and six (11\%) with undetermined types (tables 2-5).

The distribution of HPV types in the various categories of specimens from women and men is shown in table 6. HPV types 6 and 11 were found most frequently in the majority of specimen categories. However, the other types sought were found predominantly in the non-biopsy and SG specimen categories.

Samples taken from different sites of the same patient frequently contained the same HPV type. This is illustrated by samples from patients F4 and M4, the majority of which contained HPV type 6 . However, in patients

Table 5 HPV DNA findings in SG specimens from women in relation to types of specimens and times at which taken

\begin{tabular}{|c|c|c|c|c|c|c|}
\hline \multirow[b]{2}{*}{$P t$} & \multirow[b]{2}{*}{ Time } & \multicolumn{5}{|c|}{$H P V D N A$ in $S G$ specimens from } \\
\hline & & Left labia & Right labia & Fourchette & Clitoris & Anus \\
\hline F1 & $\begin{array}{l}0 \\
4\end{array}$ & $\begin{array}{l}\text { neg } \\
+\end{array}$ & $\begin{array}{l}\text { neg } \\
18\end{array}$ & $\begin{array}{l}\text { ns } \\
\text { ns }\end{array}$ & $\begin{array}{l}\text { ns } \\
\text { ns }\end{array}$ & $\begin{array}{c}\text { neg } \\
+\end{array}$ \\
\hline & 12 & neg & neg & neg & ns & neg \\
\hline F2 & 0 & $6,11,33$ & 33 & $6,11,33$ & ns & 18,33 \\
\hline & 4 & & neg & neg & $\beta$ & ns \\
\hline F3 & 0 & $6,11,18,33$ & ns & ns & ns & 6,11 \\
\hline & 2 & neg & neg & + & neg & ns \\
\hline F4 & 0 & 6,11 & $6,16,18$ & ns & ns & $6,11,18$ \\
\hline F5 & 0 & 6 & neg & 6 & ns & ns \\
\hline F6 & 0 & ns & $\beta^{\circ}$ & neg & neg & ns \\
\hline F7 & 0 & neg & neg & neg & ns & neg \\
\hline F8 & 0 & ns & ns & ns & ns & ns \\
\hline F9 & 0 & 6,11 & $\beta^{2}$ & 11 & ns & ns \\
\hline
\end{tabular}

Table 6 HPV type in relation to types of specimens

\begin{tabular}{|c|c|c|c|c|c|c|c|}
\hline \multirow{4}{*}{$\begin{array}{l}\text { HPV } \\
\text { type }\end{array}$} & \multicolumn{7}{|c|}{ Number of times (\%) HPV of specified type in given sample type } \\
\hline & \multicolumn{4}{|l|}{ Women } & \multirow{2}{*}{\multicolumn{3}{|c|}{ Men }} \\
\hline & \multirow{2}{*}{$\begin{array}{l}\text { External } \\
\text { wart }\end{array}$} & \multirow{2}{*}{$\begin{array}{l}\text { Cervical } \\
\text { biopsy }\end{array}$} & \multirow[b]{2}{*}{ Non-biopsy } & \multirow[b]{2}{*}{$S G$} & & & \\
\hline & & & & & Wart & Non-biopsy & $S G$ \\
\hline $\begin{array}{r}6 \\
11\end{array}$ & $\begin{array}{l}5(50) \\
4(40)\end{array}$ & $\begin{array}{l}2(67) \\
1(33)\end{array}$ & $\begin{array}{l}7(41) \\
3(17)\end{array}$ & $\begin{array}{r}11(34) \\
8(24)\end{array}$ & $\begin{array}{l}7(64) \\
3(27)\end{array}$ & $\begin{array}{l}4(57) \\
2(29)\end{array}$ & $\begin{array}{l}4(31) \\
2(15 \cdot 5)\end{array}$ \\
\hline 16 & - & - & $1(6)$ & $1(3)$ & - & $1(14)$ & - \\
\hline 18 & - & - & $1(6)$ & $5(15)$ & - & - & $5(38.5)$ \\
\hline 31 & $1(10)$ & - & $1(6)$ & - & - & - & $1(7 \cdot 5)$ \\
\hline 33 & - & - & $2(12)$ & $5(15)$ & $1(9)$ & - & - \\
\hline+ & & & $2(12)$ & $3(9)$ & $\overline{-}$ & $\overline{-}$ & $1(7 \cdot 5)$ \\
\hline Total & $10(100)$ & $3(100)$ & $.11(100)$ & $33(100)$ & $11(100)$ & $7(100)$ & $13(100)$ \\
\hline
\end{tabular}


in whom multiple HPV types were detected, not all the types were found in each specimen.

\section{HPV in pairs of partners}

Partner pairs F1-M3, F2-M8 and F3-M2 had HPV types in common. Partner pair F7-M9 did not (tables 3-5).

\section{Discussion}

The PCR allows the detection of very small quantities of DNA, ${ }^{7}$ so that strenuous efforts must be taken to avoid contamination of specimens. The combination of strict clinical and laboratory protocols, repeated use of positive and negative controls throughout the experiments, together with the use of Southern blotting and hybridisation to confirm results give us confidence in their validity.

HPVs have been detected in biopsy specimens from genital warts, ${ }^{15}$ acetowhite areas ${ }^{16}$ and normal genital skin. ${ }^{17}$ They have also been found in cervical scrapes from women with warts, ${ }^{18}$ urethral samples, ${ }^{19} 20$ vaginal samples, ${ }^{21} 22$ rectal swabs, ${ }^{23}$ buccal scrapes ${ }^{24}$ and serum samples. ${ }^{25}$ All these specimens, as well as SG samples, were included in our study in order to investigate the multifocal nature of anogenital HPV infections. The SG technique has been used to assess changes in the stratum corneum. ${ }^{26}$ In our study, this technique was chosen as it allowed the sampling of the skin surface with minimal trauma. Not only is this process more acceptable to patients than formal biopsy, but it also allows the monitoring of HPV-induced changes without inducing the marked inflammatory response associated with biopsy. Such a response may alter the natural history of HPV infection ${ }^{27}$ and thus assessment of the natural history should involve a sampling process which minimises this induced response. Although the number of cells harvested by the SG technique is small, the use of the PCR for the detection of the human $\beta$ globin gene allowed us to confirm that human cells were present and thus observe as closely as possible the natural history of HPV infection.

The detection of HPV DNA in $11(65 \%)$ of 17 biopsies with histological evidence of HPV infection is consistent with the findings of some, ${ }^{15}$ although the proportion is smaller than that found by others. ${ }^{17}$ Infection with HPV types other than those sought by us is a possible explanation for this small proportion and is supported by the large numbers of specimens noted to contain untyped HPVs.

The detection of HPV DNA in $12-36 \%$ of non-biopsy specimens suggests that they are valuable to obtain. Cervical scrapes have been investigated frequently for the presence of HPV DNA but, until recently, few other specimen types had been assessed. In fact, our data suggest that other non-biopsy specimen types are just as likely to contain HPV DNA as cervical scrapes.

The proportion of SG samples containing the $\beta$-globin gene was much larger in women than in men. However, the proportion of $\beta$ globin-containing SG samples containing HPV DNA did not differ between men and women. It is possible that this observation may be related to the fact that the skin of the male external genitalia is more cornified than the female counterpart. The surface layers of cornified skin predominantly contain anucleate squames which do not contain the $\beta$-globin gene. The ability to harvest infected cells by the SG method was confirmed by the observation that the majority of SG samples taken from areas with clinically apparent warts contained HPV DNA.

The presence of HPV DNA in $\beta$-globin containing SG samples from areas which did not develop acetowhite staining is consistent with the finding of HPV DNA in histologically normal skin. ${ }^{17}$ Furthermore, it suggests that staining with acetic acid may have limited value in evaluating the extent of infection with HPV and in assessing response to treatment. It is possible that areas without acetowhite changes but with detectable HPV DNA may represent passive contamination of the skin with HPV from another site of the patient, or from a sexual partner; or they may represent infection of the epithelium with HPV which has not produced sufficient cellular changes to generate visible changes following the application of acetic acid. The failure to detect HPV DNA in four biopsies and in three of nine SG samples from acetowhite areas is consistent with the knowledge ${ }^{28}$ that not all acetowhite areas develop as a result of infection with HPV. Furthermore, the finding of HPV DNA in only four of six $\beta$-globincontaining SG samples from men with acetowhite areas of the glans is in agreement with the suggestion ${ }^{29}$ that acetowhite changes of the glans may develop as a result of subclinical balanitis not related to infection with HPV.

The frequent occurrence of multiple HPV infections has been disputed, ${ }^{30}$ but our data concerning the co-existence of multiple HPV types are consistent with those of others. ${ }^{31}$ For a given patient, specific HPV types were frequently found in common in biopsy, nonbiopsy and SG specimens, as were multiple HPV types. The failure to show crosshybridisation during the repeated experiments in which there were positive and negative controls indicates that the observations regarding multiple HPV types are not spurious.

The persistence of HPV at various sample sites after treatment supports the findings of others $^{32}$ that treatment of clinical and histological abnormalities may not necessarily eradicate infection. It is likely that persistent infection explains, at least in part, the high recurrence rate of warts regardless of the method of treatment. ${ }^{33}$ However, the occurrence of common HPV types in sexual partners noted in the current study and previously, ${ }^{15}$ suggests that there may be an opportunity for reinfection also to play a role in the persistence of disease.

Multifocal infection of the anogenital area 
is recognised to occur in infection with Neisseria gonorrhoeae, Chlamydia trachomatis ${ }^{34}$ and, most recently, human papillomavirus. ${ }^{19}$ Furthermore, neoplasia of the female anogenital tract, a condition thought to be related to HPV infection, ${ }^{7}$ is frequently multifocal. ${ }^{35}$ Our data suggest that, if a sample had been taken from only one site, and at only one time, the occurrence of HPV infection, including infection with multiple HPV types, would have been underestimated. To determine the true extent of anogenital HPV infection, multiple samples need to be taken, possibly over several months. Studies in which single sites are sampled may lead to a serious underestimate of the rate of infection with HPV.

Samples from clinically uninfected areas contained a larger proportion of the "high risk" HPV types, namely types 16 and 18, than the "low risk" HPV types, 6 and 11, found predominantly in warts. This difference was particularly marked in the samples obtained by the SG technique. The preponderance of "high risk" HPV types in specimens other than those taken from clinically apparent warts has been noted previously, for example in specimens obtained from acetowhite areas, ${ }^{36}$ cervical scrapes ${ }^{18}$ and urethral swab specimens. ${ }^{19} 37$ Our understanding of the epidemiology of anogenital HPV infection, in particular the development of neoplasia, must take into account the detection of HPV in specimens from areas without clinically apparent disease. The problem has arisen because of the use of the highly sensitive PCR which is capable of detecting a few virus particles. Other factors, including quantity of virus present and host immunity, ${ }^{27}$ may be at least as important as the mere presence of a few viral particles in the development of any clinical abnormalities. However, only by obtaining a clear understanding of the epidemiology of anogenital HPV infections will it be possible to develop rational approaches to their management.

1 Oriel JD. Natural history of genital warts. $B r f$ Venereal Dis 1971;47:1-13.

2 Barrett TJ, Silbar JD, McGinley JP. Genital warts-a venereal disease. $\mathcal{F} A M A$ 1955;154:333-4.

3 Koutsky L. Role of epidemiology in defining events that influence transmission and natural history of anogenital influence transmission and natural history of anogenital papillomar

4 Toon PG, Arrand JR, Wilson LP, Sharp DS. Human papillomavirus infection of the uterine cervix of women without cytological signs of neoplasia. BMf 1986;293 $1261-4$.

5 Fuchs PG, Girardi F, Pfister H. Human papillomavirus DNA in normal, metaplastic, preneoplastic and neoplastic epithelia of the cervix uteri. Int $\mathcal{f}$ Cancer 1988 41:41-5.

6 Muñoz N, Bosch X, Kaldor JM. Does human papillomavirus cause cervical cancer? The state of the epidemiological evidence. Br. $\mathcal{F}$ Cancer 1988;57:1-5.

7 Syrjänen KJ. Epidemiology of human papillomavirus (HPV) infections and their associations with genital (HPV) infections and their associations with
squamous cell cancer. APMIS 1989;97:957-70.

8 De Villiers E-M. Laboratory techniques in the investigation of human papillomavirus infection. Genitourin Med $1992 ; 68: 50-4$.

9 Southern EM. Detection of specific sequences among DNA fragments separated by gel electrophoresis. $\mathcal{f} M o l$

10 Hillman RJ, Walker MM, Harris JRW, Taylor-Robinson D. Penile dermatoses: a clinical and histopathological study. Genitourin Med 1992;68:166-9.

11 Cann AJ, Zack JA, Go AS, et al. Human immuno- deficiency virus type $1 \mathrm{~T}$-cell tropism is determined by events prior to provirus formation. If Virol 1990;64 4735-42.

12 Snijders PJF, van den Brule AJC, Schrijnemakers HFJ, Snow G, Meijer CJLM, Walboomers JMM. The use of general primers in the polymerase chain reaction permits the detection of a broad spectrum of human papillomavirus genotypes. f Gen Virol 1990;71:173-81.

13 Hillman RJ, Botcherby M, Ryait BK, Taylor-Robinson D. Detection of human papillomavirus DNA in the urogenital tracts of men with anogenital warts. Sex Transm Dis 1993;20:21-7.

14 Hillman RJ, Ryait BK, Botcherby M, Taylor-Robinson D. Human papillomavirus DNA in the urogenital tracts Human papillomavirus DNA in the urogenital tracts of men with gonorrhoea, penile warts

15 Wickenden $\mathrm{C}$, Hanna $\mathrm{N}$, Taylor-Robinson $\mathrm{D}$, et al. Sexual transmission of human papillomaviruses in heterosexual and male homosexual couples, studied by DNA hybridisation. Genitourin Med 1988;64:34-8

16 Campion MJ, McCance DJ, Mitchell HS, Jenkins D, Singer A, Oriel JD. Subclinical penile human papillomavirus infection and dysplasia in consorts of women with cervical neoplasia. Genitourin Med 1988;64:90-9.

17 Katelaris PM, Cossart YE, Rose BR, et al. Human papillomavirus: the untreated male reservoir. $f$ Urol 1988; 140:300-5.

18 Kiviat NB, Koutsky LA, Paavonen JA, et al. Prevalence of genital human papillomavirus infection among women attending a college student health clinic or a sexually attending a college student health clinic or a sexually transmitted

19 Rymark P, Forslund O, Hansson BG, Lindholm K Genital HPV infection not a local but a regional infection: experience from a female teenage group. Genitourin Med 1993;69:18-22.

20 Rosemberg SK, Greenberg MD, Reid R. Sexually transmitted papillomaviral infection in men. Obstet Gynecol Clin North Am 1987;14:495-512.

21 Morris BJ, Flanagan JL, McKinnon KJ, Nightingale BN Papillomavirus screening of cervical lavages by polymerase chain reaction. Lancet 1988;ii:1368.

22 Fairley CK, Chen S, Tabrizi SN, Quinn MA, McNeil J, Garland SM. Tampons: a novel patient-administered method for the assessment of genital human papillomethod for the assessment of genital human
mavirus infection. $\mathcal{F}$ Infect Dis 1992;165:1103-6.

23 Law CLH, Qassim M, Thompson CH, et al. Factors associated with clinical and sub-clinical anal human papillomavirus infection in homosexual men. Genitourin Med 1991;67:92-8.

24 Jenison SA, Yu X-P, Valentine JM, et al. Evidence of prevalent genital-type human papillomavirus infection in adults and children. $f$ Infect Dis 1990;162:60-9.

25 Pao CC, Lin S-S, Lin C-Y, Maa J-S, Lai C-H, Hsieh T-T. Identification of human papillomavirus DNA sequences in peripheral blood mononuclear cells. Am $\mathcal{F}$ Clin Pathol 1991;95:540-6.

26 Marks R, Dawber' RPR. Skin surface biopsy: an improved technique for the examination of the horny layer. $\mathrm{Br} F$ Dechnique for the examinat $1971 ; 84: 117-23$.

27 Kirchner $\mathrm{H}$. Immunobiology of human papillomavirus infection. Prog Med Virol 1986;33:1-41

28 Hippeläinen M, Yliskoski M, Saarikoski S, Syrjänen S Syrjänen $K$. Genital human papillomavirus lesions of the male sexual partners: the diagnostic accuracy of peniscopy. Genitourin Med 1991;67:291-6.

29 Griffiths M, Penna LK, Tovey SJ. Aceto-white change of the glans penis associated with balanitis not human papillomavirus infection. Internat $\mathcal{f}$ STD $\mathcal{E}$ AIDS 1991; 2:212-3.

30 Beckmann AM, Sherman KJ, Myerson D, Daling JR McDougall JK, Galloway DA. Comparative virologic studies of condylomata acuminata reveal a lack of dual infections with human papillomaviruses. $\mathcal{F}$ Infect Dis 1991;163:393-6.

31 Wikström A, Lidbrink P, Johansson B, von Krogh G. Penile human papillomavirus carriage among men attending Swedish STD clinics. Internat $₹$ STD E AIDS 1992;2:105-9.

32 Steinberg BM, Topp WC, Schneider PS, Abramson AL. Laryngeal papillomavirus infection during clinical remission. N Engl F Med 1983;308:1261-4.

33 Ferenczy A, Mitao M, Nagai N, Silverstein SJ, Crum CP. Latent papillomavirus and recurrent genital warts. $N$ Eng $\mathcal{F}$ Med 1985;26:784-8.

34 Chernesky $M$, Sellors J, Mahony J, Jang D, Pickard L, Krepel J. Diagnosis of C. trachomatis infections in women by examining cervical and urethral swabs and urine with culture and enzyme immunoassay. In: Bowie $\mathrm{W}$, Caldwell $\mathrm{H}$, Jones $\mathrm{R}$, et al eds. Chlamydial infections, Proceedings of the Seventh International Symposium on Proceedings of the Seventh International Symposium on

35 Campion MJ, Clarkson P, McCance DJ. Squamous neoplasia of the cervix in relation to other genital tract neoplasia. Clin Obstet Gynecol 1985;12:265-80

36 Barrasso R, De Brux J, Croissant O, Orth G. High prevalence of papillomavirus-associated penile intraepithelial neoplasia in sexual partners of women with cervical intraepithelial neoplasia. $N$ Engl $\mathcal{f}$ Med 1987;317: 916-23.

37 Rosemberg SK. Sexually transmitted papillomaviral infection in men: an update. Dermatol Clin 1991;9:317-31. 